\title{
From Yugoslavia
}

\author{
T Dürrigl
}

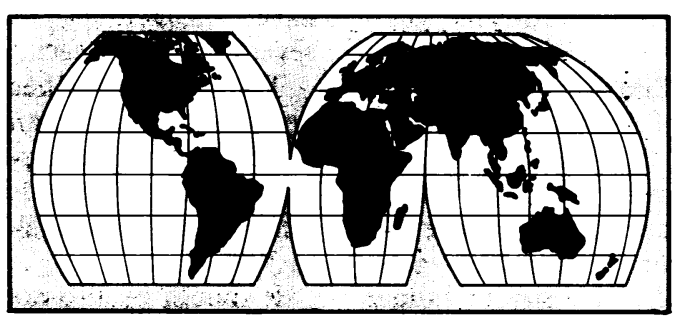

Rheumatology in Yugoslavia has a rich tradition of over 60 years because as early as 1928 Drago Čop founded the first rheumatology outpatient unit, in Zagreb (Croatia). In 1949 the Yugoslav Rheumatological Association was founded, and in 1953 the first rheumatology journal Reumatizam was started (editor Drago Čop until 1963, thereafter T Dürrigl). A second journal was started in 1971-Acta Rheumatologica Belgradensia (originator Zagorka Berović, editors I Stojanović and V Mladenović). The Yugoslav Rheumatological Association has to date organised 10 congresses.

In Yugoslavia rheumatology is not an autonomous medical specialty, but postgraduate education in rheumatology takes place at the medical schools in Belgrade and Zagreb for specialists in internal medicine and in physical medicine and rehabilitation, leading to a master of sciences degree. At medical schools rheumatology is taught within the framework of internal medicine and also, partly, orthopaedics.

During 1989 and 1990 the Yugoslav Rheumatological Association organised several international and national symposiums. Thus in 1989 Abano Terme (Italy) hosted the second Italian-Yugoslavian rheumatology meeting to consider inflammatory rheumatic diseases, and in June 1990 the second symposium of rheumatologists of Poland and Yugoslavia was held in Iwonicz-Zdroj (Poland). At this symposium Yugoslav authors outlined new therapeutic methods and gave details of current research (Tanja Kveder and B Rozman, Clinical and biochemical aspects of antibodies against some ribonucleoproteins; B Božić et al, Antiphospholipid syndrome; A Jelčić et al, Phagocytic activity in rheumatoid arthritis; Mojca Kos-Golja et al, Diagnosis of changes in small joints by magnetic resonance; $\mathrm{Z}$ Domljan et al, Early diagnosis of psoriatic arthritis).

A European osteoarthrology symposium was held in Dubrovnik in September 1990, under the auspices of EULAR (organiser Professor I Jajić). Rheumatologists and other scientists from Europe, America, and Asia presented 106 papers. On that occasion Professor W B van den Berg was elected president of the European Society of Osteoarthrology, thus succeeding Professor S Havelka. This symposium was followed by the first European conference on the epidemiology of rheumatic diseases, at which 60 papers were presented on topics such as the epidemiology of musculoskeletal diseases developing at work and the epidemiological characteristics of rheumatoid arthritis, scleroderma, and similar diseases. This symposium was also held under the patronage of EULAR. Yugoslav rheumatologists played an active part too at the international rheumatology congress in Rio de Janeiro, the fourth rheumatology symposium in Prague, the sixth annual meeting of Britain's rheumatologists, the sixth EULAR symposium in Athens, and the fifth Mediterranean congress of rheumatologists.

The most important meeting in Yugoslavia was the fifth 'Rheumatology days' meeting organised by Professor T Dürrigl and Dr Ž Maštrović, which was held in Zadar (Dalmatia) in May 1990, and traditionally takes place every four years. The topic was psoriatic arthritis, and the introductory paper was given by Professor H G Fassbender from Mainz (Germany). In 1990, also, the 150th anniversary of systematic treatment of rheumatic patients was celebrated in our oldest spaVaraždinske Toplice, which was used by the Romans 2000 years ago. In 1989 three large meetings were held: firstly, a meeting on the treatment of locomotor diseases, secondly a symposium of paediatric rheumatologists, which discussed the treatment of juvenile chronic arthritis, and, thirdly, a meeting of rheumatologists from the republics of Slovenia and Croatia.

All Yugoslav republics have vigorous rheumatology programmes. In Serbia the committee on rheumatism held eight courses for general practitioners and two symposiums on rheumatic fever, which is still a considerable problem in certain parts of Serbia. The rheumatology section of the Serbian Medical Association held 15 scientific meetings. In Niška Banja spa a rheumatology symposium took place. Each year the medical faculty in Belgrade organises a meeting entitled 'New trends in medicine', and in 1990 one of the topics was rheumatology. The Institute for Rheumatology in Belgrade celebrated its 25th anniversary in 1990 with a very interesting scientific meeting, at which papers from all fields of rheumatology were presented. In Kosovo 'Rheumatology-physiatric days' take place every year, as well as consultations on rheumatic fever.

The rheumatology section of the Croatian Medical Society held a number of scientific meetings about ultrasound diagnostics, psychosomatic diseases in rheumatology, low back pain in industrial workers, and criteria for evaluation and follow up of rheumatoid arthritis. Additionally, a register for rheumatic diseases was started, to give insight into the prevalence, of these diseases in Croatia, but there are difficulties as registering of rheumatic diseases is not obligatory.

Rheumatologists of Slovenia organised a symposium in Catež spa on the occasion of its 25 th anniversary. In this republic the scientific research 
of the university rheumatology clinic in Ljubljana must be mentioned, particularly the investigations of autoantibodies carried out by B Rozman, Prim Mojca Kos-Golja, Tanja Kveder, and others. The immunology laboratory of this clinic was included in a multicentre study evaluating the reproducibility of tests for ribonucleoproteins. It included testing antibodies against the antigens Sm, nRNP, Ro, and La. Only the Ljubljana clinic and one other laboratory correctly determined the required antibodies. This clinic in Ljubljana celebrated its 20th anniversary in October 1990 by holding a scientific symposium on autoimmunity. Eminent guest lecturers (Y Schoenfeld, Tel-Aviv; W van Venrooij, Nijmegen; S Bombardieri, Pisa; J Smolen, Vienna) and the rheumatologists of Ljubljana's rheumatology clinic presented their latest research achievements: characterisation of $R_{0}$ and $\mathrm{La}$ antigens (B Božić et $a l$ ), counterimmunoelectrophoresis: false positive or undescribed autoantibodies (T Kveder $e t a l$ ), diversity of human spleen antigens recognised by serum samples of autoimmune patients (B Lestan et al), anti-Ro antibodies and affection of the myocardium in adults with systemic lupus erythematosus (D Logar et $a l)$, and hypertension renal vascular lesions in patients with lupus glomerulonephritis (J Petrin et al). The organiser and chairman of this symposium was Professor B Rozman.

Apart from research, in Slovenia great attention is given to the education of rheumatic patients. Thus in 1989 the fifth anniversary of the Society of Patients with Ankylosing Spondylitis (founded by Professor Anton Franović, and closely connected with similar societies in Europe) was celebrated.

Bosnia and Macedonia medical societies also have rheumatology sections, which organise several meetings each year.

The Yugoslav Rheumatological Association is preparing an international symposium on hypertrophic osteoarthropathy (Dubrovnik, 9-11 September 1991), and the 11th Yugoslav rheumatology congress will take place in Sarajevo (Bosnia) in 1992.

It should be also noted that the ex-president of our society, Professor Ivo Jajić, was elected as an honorary member of the rheumatology societies of Bulgaria and the German Democratic Republic. 